\title{
Untapping the potential of sulfur isotope analysis in biominerals
}

\author{
Zoë A. Doubleday ${ }^{1, *}$, John Cliff ${ }^{2,3}$, Christopher Izzo ${ }^{1,4}{ }^{,}$Bronwyn M. Gillanders ${ }^{1}$ \\ ${ }^{1}$ School of Biological Sciences, The University of Adelaide, Adelaide, SA 5005, Australia \\ ${ }^{2}$ Centre for Microscopy, Characterisation and Analysis, The University of Western Australia, Perth, WA 6009, Australia \\ ${ }^{3}$ Present address: Environmental Molecular Sciences Laboratory, Pacific Northwest National Laboratory, Richland, \\ WA 99354, USA \\ ${ }^{4}$ Present address: Fisheries Research and Development Corporation, Adelaide, SA 5000, Australia
}

\begin{abstract}
Sulfur isotope ratios are used to untangle food web dynamics, track animal movements and determine dietary provenance. Yet, their application in the biomineralised tissues of animals is relatively unexplored. These tissues are particularly useful for isotopic analyses as they can retain a permanent and temporally resolved chemical record over the lifetime of the organism. We experimentally determined whether biogenic carbonate records environmental variation in sulfur isotope ratios $\left({ }^{34} \mathrm{~S} /{ }^{32} \mathrm{~S}\right)$ in an aquatic system and whether such variation is influenced by the ambient water or diet. Juvenile barramundi Lates calcarifer were raised in 2 water treatments with differing sulfur isotope ratios, as well as 3 diet treatments with differing ratios. We subsequently analysed the calcium carbonate fish ear bones (otoliths) using secondary ion mass spectrometry, a technique that allowed the experimental growth of the otolith to be targeted. Our findings suggest that biogenic carbonate records variation in sulfur isotope ratios and that diet is not the sole source of sulfur isotope variation in aquatic consumers. Drawing from a multi-disciplinary body of literature, we also reviewed the potential ecological and environmental applications of sulfur isotope analysis in biominerals. We emphasise the extensive application of sulfur isotope ratios and that progressing this field of research to include biominerals is a worthwhile pursuit.
\end{abstract}

KEY WORDS: Carbonates - Sulfur isotopes - Diet $\cdot$ Fish otolith $\cdot$ Barramundi $\cdot$ Lates calcarifer

\section{INTRODUCTION}

The analysis of stable isotopes in plant and animal tissue is used widely in the fields of ecology and environmental science (Boecklen et al. 2011). A range of elements has been targeted, from hydrogen to lead, each with its own isotopic properties and applications (Peterson \& Fry 1987, Rubenstein \& Hobson 2004). For sulfur, geochemical, biological and anthropogenic processes drive relative differences in abundance between the 2 principal isotopes, ${ }^{34} \mathrm{~S}$ and ${ }^{32} \mathrm{~S}$, resulting in marked isotopic variation in the environment (Thode 1991). Organisms living in marine, freshwater and terrestrial environments have distinct

*Corresponding author: zoe.doubleday@adelaide.edu.au sulfur isotope ratios, which in turn can be influenced by local oxygen levels (aerobic versus anaerobic conditions), precipitation, geology and pollution (Rubenstein \& Hobson 2004, Nehlich 2015). These properties make sulfur isotopes an attractive tool to investigate food web dynamics, movement patterns and dietary provenance (Trust \& Fry 1992, Connolly et al. 2004, Fry \& Chumchal 2011), and to track pollution (Barros et al. 2015), but still remain a relatively untapped resource in the field (compared to carbon, oxygen and nitrogen isotopes).

In animal studies, organic tissues, such as muscle and bone collagen, are typically used for sulfur isotope analysis. However, biominerals, such as coral

(C) The authors 2018. Open Access under Creative Commons by Attribution Licence. Use, distribution and reproduction are unrestricted. Authors and original publication must be credited. 
skeletons, mollusc shells and fish otoliths, represent an underused alternative to organic tissue. An advantage of biomineralised tissues is that many grow incrementally, providing a time-resolved chemical record throughout the lifetime of the organism, and are preserved in the environment long after the organism has died (although taphonomic processes can alter isotope ratios over time). This enables environmental and ecological phenomena to be tracked over decadal, centennial and even millennial time scales (Rowell et al. 2010, Limburg et al. 2011, Izzo et al. 2017). Further, extensive archives of biominerals already exist in government research agencies, universities and museums, whereby data can be generated retrospectively with relatively minimal cost. Sulfur isotopes were first measured in biomineralised tissue (fish otoliths) by Weber et al. (2002) using secondary ion mass spectrometry (SIMS), a spatially resolved technique that allows the temporal properties of biominerals to be exploited. Since then, few studies have investigated sulfur isotopes in biominerals, but those that do exist have used SIMS to investigate the source and movement of hatchery salmonids (Godbout et al. 2010, Johnson et al. 2012) and to develop a tracer of hypoxia exposure (Limburg et al. 2015). Further work has also been done to develop a bulk analytical method, using isotope ratio mass spectrometry (IRMS), for biogenic apatite (Goedert et al. 2016) .

In the limited studies to date, it has been assumed that sulfur isotope ratios in biominerals, specifically otolith carbonate, are influenced solely by the diet, such that the ratio of an animal's food determines the value in biomineralised tissue (Godbout et al. 2010, Johnson et al. 2012). Yet, in aquatic environments, it is suggested that sulfated macromolecules, sourced from inorganic sulfate in the water, could be incorporated into the organic matrix of the otolith (Mugiya \& Iketsu 1987, Weber et al. 2002, McFadden et al. 2016). Determining the source of isotopic variation in biominerals (i.e. water or diet) has implications for how isotopic signatures are applied and interpreted (see Doubleday et al. 2013, Izzo et al. 2015 for analogous studies on elemental markers). Using an experimental approach, we explicitly determined in an aquatic system (1) whether otolith carbonate reflects environmental variation in sulfur isotope ratios, and (2) whether that variation is influ- enced by both the isotopic composition of the diet and the surrounding water. In addition, we reviewed relevant literature to highlight the suite of potential applications of sulfur isotope ratios to ecological and environmental science. Our aim was not to undertake an exhaustive review, but rather to focus on applications that are translatable to biominerals.

\section{MATERIALS AND METHODS}

\section{Aquarium experiment}

We raised juvenile fish in an orthogonal experimental design consisting of 2 water treatments with differing sulfur isotope ratios, as well as 3 diet treatments with differing ratios ( $\mathrm{n}=6$ treatments; Table 1$)$. Each treatment was replicated $(\mathrm{n}=12$ tanks). We selected diadromous fish for the experiment (barramundi Lates calcarifer), as they are adapted to both marine and freshwater environments. Juvenile fish, 1.5 to $3 \mathrm{~g}$ in size, were obtained from a local commercial hatchery (Robarra) and reared under experimental conditions at the University of Adelaide, South Australia. Fish were fed daily, and feeding behaviour (rate) was monitored and scored from 0 (no feeding) to 3 (high-level feeding). Fish were exposed to experimental conditions for 30 to $34 \mathrm{~d}$ and subsequently euthanised and weighed.

\section{Food and water isotope analyses}

To confirm that isotope ratios $\left({ }^{34} \mathrm{~S} /{ }^{32} \mathrm{~S}\right)$ between water and diet treatments differed, duplicate water and diet samples were analysed using IRMS. Water

Table 1. Description of experimental treatments with mean $( \pm \mathrm{SE})$ elemental sulfur concentration (ppm) and ${ }^{34} \mathrm{~S} /{ }^{32} \mathrm{~S}$ values (expressed as $\delta^{34} \mathrm{~S} \%$, the deviation relative to Vienna Canyon Diablo Troilite) of each treatment $(\mathrm{n}=2)$

\begin{tabular}{|c|c|c|c|}
\hline Treatment & Description & $\begin{array}{c}\text { Sulfur } \\
\text { concentration }\end{array}$ & $\delta^{34} \mathrm{~S} \%$ \\
\hline \multicolumn{4}{|l|}{ Water } \\
\hline Freshwater & Borewater (0\% salinity) & $290 \pm 42$ & $11.0 \pm 0.1$ \\
\hline Seawater & Natural seawater (40\%o salinity) & $3770 \pm 64$ & $20.7 \pm 0.4$ \\
\hline \multicolumn{4}{|l|}{ Diet origin } \\
\hline Freshwater & $\begin{array}{l}\text { Freeze-dried tubifex worms } \\
\text { Tubifex tubifex }\end{array}$ & $6132 \pm 27$ & $4.9 \pm 0.4$ \\
\hline Mixed & $\begin{array}{l}\text { Commercial pellet food } \\
\text { (Luckystar brand) }\end{array}$ & $5887 \pm 40$ & $12.3 \pm 0.3$ \\
\hline Marine & $\begin{array}{l}\text { Freeze-dried Antarctic krill } \\
\text { Euphausia superba }\end{array}$ & $11403 \pm 49$ & $15.6 \pm 0.4$ \\
\hline
\end{tabular}


samples were analysed by a commercial provider (Environmental Isotopes, New South Wales), whereby they were evaporated (to concentrate the sulfur), acidified, heated, mixed with $\mathrm{BaCl}_{2}$ solution and cooled. The $\mathrm{BaSO}_{4}$ precipitate was then filtered and dried for isotope analysis. The $\mathrm{BaSO}_{4}$ precipitate (approximately $0.1 \mathrm{mg}$ ) was mixed with $\mathrm{V}_{2} \mathrm{O}_{5}$ in tin (Sn) cups and then combusted using a modified Roboprep Elemental Analyser attached to a Finnigan Mat Conflo III and Finnigan 252 IRMS. Samples were analysed relative to an internal gas standard and solid laboratory-specific standards $\left(\mathrm{Ag}_{2} \mathrm{~S}-3: \delta^{34} \mathrm{~S}=\right.$ $+0.4 \%$ Vienna Canyon Diablo Troilite [VCDT]; CSIRO-S-SO ${ }_{4}: \delta^{34} \mathrm{~S}=+20.4 \%$ VCDT), which were used to correct the raw data. The internal solid laboratory standards were calibrated using international standards IAEA-S1 $\left(\delta^{34} \mathrm{~S}=-0.3 \% \mathrm{VCDT}\right)$ and NBS$127\left(\delta^{34} \mathrm{~S}=+20.3 \% \mathrm{VCDT}\right)$. The reproducibility of the sulfur isotope values of $\mathrm{BaSO}_{4}$ was $<0.2 \%$. To obtain elemental sulfur concentrations, additional water samples were analysed by a commercial provider (National Measurement Institute, Australia) using inductively coupled plasma optical emission spectrometry (Agilent / Varian 730-ES instrument).

The food samples were analysed in-house at the University of Adelaide for both isotope values and elemental sulfur concentrations. Samples were powdered and placed in Sn cups and combusted using a EuroVector Euro Elemental Analyzer in-line with a $\mathrm{Nu}$ Instruments CF-IRMS. Samples were analysed relative to internal laboratory standards, as above, traceable to IAEA-S2 and IAEA-S3 standards $\left(\delta^{34} \mathrm{~S}=\right.$ +22.7 and $-32.3 \%$ VCDT, respectively). Reproducibility was $<0.1 \%$. Elemental concentrations were determined by comparing the peak areas of SO. ${ }_{2}$ with the known weights of sulfur in the standards. All ratios for food and water samples were expressed in per mil as $\delta^{34} \mathrm{~S} \%$, the deviation relative to VCDT, and elemental concentrations in ppm (Table 1).

\section{Otolith preparation and isotope analyses}

Otoliths (size: $\sim 3 \times 1 \mathrm{~mm}$ ) were dissected from fish, cleaned in ultra-pure water and air-dried. A subsample of otoliths was cut in half at the core using a diamond saw, embedded in epoxy resin, ground until the transverse plane and core were exposed and polished to $1 \mu \mathrm{m}$. The sample mounts were sonicated successively in detergent, distilled deionized water and isopropyl alcohol, and then coated with $30 \mathrm{~nm}$ of gold (see Fig. S1 in the Supplement at www.intres.com/articles/suppl/m598p159_supp.pdf). Otoliths were analysed in 2 consecutive sessions using SIMS (Cameca IMS 1280) at the Centre for Microscopy, Characterisation, and Analysis, University of Western Australia, Australia. Sample otoliths were sputtered with a $4 \mathrm{nA}, 20 \mathrm{keV} \mathrm{Cs}{ }^{+}$primary ion beam and initially presputtered with a $25 \times 25 \mu \mathrm{m}$ raster. Following automatic centring in the field and contrast apertures, the analyses consisted of integrated $20 \times$ 4 s cycles using a $20 \times 20 \mu \mathrm{m}$ rastered beam with dynamic transfer enabled. Duplicate analyses were made on the edge of each otolith cross section, representing the experimental period of otolith growth (Fig. S1). This also ensured that data were not confounded by ontogenetic effects. A normal incidence electron gun was used for charge compensation. ${ }^{32} \mathrm{~S}^{-}$ ions were collected in a Faraday cup (FC) with a $10^{11}$ ohm amplifier resistor, and ${ }^{34} \mathrm{~S}^{-}$ions were collected simultaneously with an electron multiplier (EM). Average intensity for ${ }^{32} \mathrm{~S}^{-}$ions was $\sim 3 \times 10^{6} \mathrm{cps}$. The background of the FC was characterized before each analytical session for data correction. Other parameters included an entrance slit of $120 \mu \mathrm{m}$, exit slit widths of $500 \mu \mathrm{m}, 40 \mathrm{eV}$ energy slit width with a $5 \mathrm{eV}$ offset. Data correction was limited to FC background subtraction and EM deadtime correction.

Sample analyses were bracketed by 8 to 10 external standard analyses to correct for instrumental mass fractionation, which was judged to be negligible. We used an otolith section, sourced from a marine fish (snapper Chrysophrys auratus Sparidae), as an external standard. The standard had a homogeneous, but unknown isotopic composition, and served to estimate analysis reproducibility. Propagation of uncertainty included internal uncertainty for each analysis (SE of $20 \times 4$ s cycles) and the external uncertainty of the otolith standard analyses. Over the course of 2 analytical sessions, internal precision averaged $0.4 \%$ (1 SD) and external precision for the otolith standard for all analyses was $0.7 \%$ ( $1 \mathrm{SD}, \mathrm{n}=27)$. Unlike the food and water analyses, which were expressed using the standardised method for reporting sulfur isotope ratios (i.e. $\delta^{34} \mathrm{~S} \%$, the deviation relative to the VCDT standard), otolith data were expressed as ${ }^{34} \mathrm{~S} /{ }^{32} \mathrm{~S}$ values, as our standard $\delta^{34} \mathrm{~S}$ composition was unknown. While this precludes data comparisons among studies, it still allows for comparisons between experimental treatments.

A proportion of the prepared samples were not analysed by SIMS (19 out of 48), because they were either completely or partially obscured by epoxy resin. The samples that were analysed were subsequently viewed under a microscope and photographed to determine whether the rasters were in the 
Table 2. Number of samples analysed per treatment and number of replicate tanks represented per treatment

\begin{tabular}{|lccc|}
\hline Treatment & Diet & Fish (n) & Tanks (n) \\
\hline Freshwater & Tubifex worms & 2 & 1 \\
& Pellet & 3 & 1 \\
& Krill & 6 & 2 \\
Seawater & Tubifex worms & 6 & 2 \\
& Pellet & 4 & 2 \\
& Krill & 4 & 1 \\
\hline
\end{tabular}

correct position and the edge of the otolith was correctly targeted (Fig. S1). Otolith and epoxy material was clearly distinguishable, such that if the otolith material was coated in epoxy it was not visible. A small number of analysed samples $(n=4)$ were removed from the final dataset because the growing edge of the otolith was not fully exposed in the epoxy mount and the SIMS analyses did not represent experimental otolith growth $(\mathrm{n}=25$ remaining samples, see Table 2 for more details).

\section{Statistical analyses}

The mean of each duplicate otolith analysis was used as the final ratioed value for each individual (see Table S1 for raw data). Differences in otolith ratios among water and diet treatments were tested using a 2-factor permutational ANOVA with water and diet treatments as fixed factors (Primer/PERMANOVA). If significant differences were detected, post hoc pairwise tests were performed. An additional ANOVA was also conducted with tank as a nested term. No significant differences were observed between replicate tanks ( $p>0.05)$, thus data from each replicate were pooled for the final analysis. One-factor ANOVAs were also performed to determine differences among water and diet treatments.

\section{RESULTS}

Water and diet samples had significantly different sulfur isotope ratios (1-factor ANOVAs: $\mathrm{p}<0.05$ ) and also matched the expected values measured in marine and freshwater environments (Table 1). Elemental sulfur concentrations also varied significantly among all treatments $(p<0.05)$, except between the pellet and tubifex diet treatments (post hoc test: $p>0.05$ ).

Mean feeding scores (for all fish raised) were highest for fish fed pellets and lowest for fish raised in freshwater and fed tubifex worms and krill (Fig. S2). By the end of the experiment, fish fed commercial pellets were also approximately 6 times larger for both freshwater and seawater treatments (mean \pm SE body weight of analysed samples: $12.1 \pm 1.7$ and $11.5 \pm 1.0 \mathrm{~g}$, respectively), compared to the other 2 diets (krill: $3.1 \pm 0.3$ and $3.3 \pm 0.5 \mathrm{~g}$; tubifex worms: $1.7 \pm 0.3$ and $2.2 \pm 0.3 \mathrm{~g}$, respectively).

Sulfur isotope ratios in otoliths varied significantly among fish exposed to the various experimental treatments (Fig. 1). Fish raised in freshwater and seawater had different sulfur isotope ratios (2-factor ANOVA: $\left.F_{1,19}=18.1, \mathrm{p}<0.001\right)$, with fish raised in
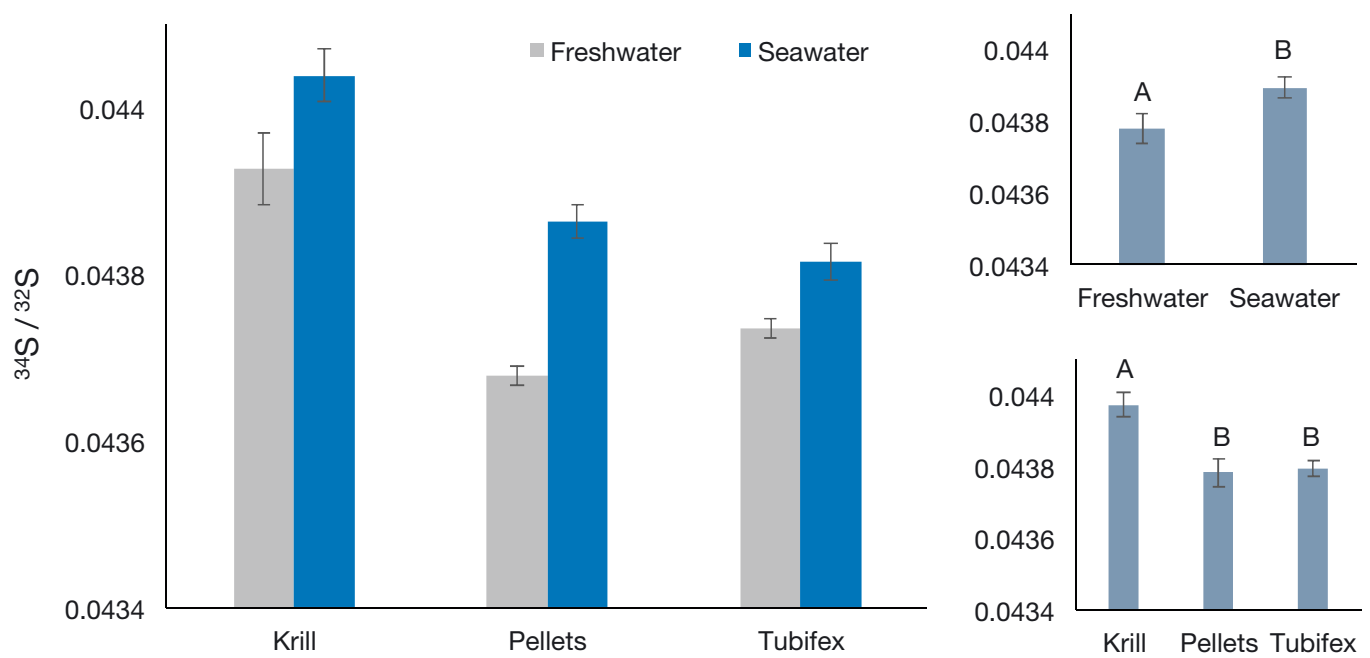

Fig. 1. Mean $( \pm \mathrm{SE})$ otolith ${ }^{34} \mathrm{~S} /{ }^{32} \mathrm{~S}$ values from barramundi raised in freshwater versus seawater and fed freshwater origin (tubifex worms), mixed origin (pellets) or marine origin (krill) diets (see Table 1). Smaller graphs represent pooled otolith

${ }^{34} \mathrm{~S} /{ }^{32} \mathrm{~S}$ values (main effects) for water and diet, with significant differences represented by different letters $(p<0.001)$ 
freshwater having lower ratios regardless of diet type. Fish fed different diets also had significantly different sulfur isotope ratios (2-factor ANOVA: $F_{2,19}=25.7, \mathrm{p}<0.001$ ), with fish fed krill having higher ratios compared to fish that were fed pellets or tubifex worms (post hoc tests: $p<0.001$, see also Fig. 1). There were no interaction effects between water and diet treatments.

\section{DISCUSSION}

We experimentally demonstrated that otolith carbonate reflects environmental variation in sulfur isotopes. Critically, fish raised in seawater had higher sulfur isotope ratios compared to fish raised in freshwater, and fish fed marine origin diets had higher ratios than fish fed mixed- or freshwater origin diets. These findings imply that sulfur isotope ratios in otolith carbonate are not just influenced by diet, but also by water chemistry. Our 2 treatments were mainly represented by 2 different oxidation states of sulfur: the reduced form, sulfide, mainly present in the fish food (as amino acids), and the oxidised form, sulfate, mainly present in the water. Both of these forms of sulfur are thought to occur in otoliths and may explain how water and diet can both influence sulfur isotope ratios. Otoliths of teleost fish are composed of aragonite crystals, which crystallise around a protein matrix with daily periodicity (Campana 1999, Dauphin \& Dufour 2008). The collagen-like protein (called otolin) makes up $2-10 \%$ of the otolith material (Murayama et al. 2002, Izzo et al. 2016), and sulfur-bearing amino acids (methionine and cysteine) in the protein are thought to be the primary source of sulfur in otoliths (Kalish 1989, McFadden et al. 2016). Methionine is essential to fish, and can only be sourced from the diet, and while cysteine can be synthesised (from methionine), dietary sources are required if utilisation exceeds synthesis ( $\mathrm{Li}$ et al. 2009). However, sulfate may also be present in otoliths in a class of proteins called proteoglycans (Weber et al. 2002, McFadden et al. 2016), and supports previous preliminary evidence that inorganic sulfate in the water can be incorporated in the otolith under experimental conditions (Mugiya \& Iketsu 1987). Sulfate has also been found in biogenic carbonates (e.g. brachiopod shells and coral skeletons) as structurally substituted ions within the carbonate lattice (Kampschulte et al. 2001, Kampschulte \& Strauss 2004, Perrin et al. 2017), a process which is also thought to occur in bioapatite (Martin et al. 2017). This study provides evidence that water and diet can both influence sulfur isotope ratios in otolith carbonate, but measuring ratios in the organic and inorganic components of the otolith, as well as determining the proportional contributions of each treatment, would help unlock the potential of sulfur isotope analysis in biominerals.

Our results also support the assumption that diet does affect sulfur isotope ratios in otoliths; however, interestingly, the sulfur isotope ratios in the otoliths of the fish fed mixed and freshwater diets did not differ. This may be explained by differences in feeding and growth. Fish fed the freshwater diet (tubifex worms) were poor feeders and 5 times smaller (by the end of the experiment) than fish fed commercial pellets. This is probably associated with the enhanced palatability and nutritional quality of the commercial pellet feed, which was specifically designed for barramundi aquaculture. As such, the fish fed tubifex worms probably had a lower proportion of experimental dietary sulfur incorporated into their otoliths (even though elemental sulfur concentrations were similar between the 2 diet types). The nutritional characteristics of food may also directly influence the effect diet has on sulfur isotope ratios in the otolith. Different levels of inorganic matter in the diet, for instance, can alter the proportion of inorganic and organic sulfur in animal tissues, which in turn affects the isotope ratio (McCutchan et al. 2003). Analysing the nutritional characteristics of the diet treatments in future studies would be a critical step to clarify the mechanisms of how diet affects sulfur isotope ratios in otolith carbonate (see Nelson et al. 2011 for similar experimental work on carbon isotopes).

Only 5 known studies have investigated the use of sulfur isotopes in biominerals, with 4 based on otolith carbonate and mostly focussed on tracking the movement and life history of salmonid fish (Weber et al. 2002, Godbout et al. 2010, Johnson et al. 2012, Limburg et al. 2015). The potential application of sulfur isotopes in biominerals is much more extensive, ranging from environmental reconstruction to the study of evolution (Table 3). Sulfur isotopes are particularly useful for determining the movement patterns of animals across the land-sea-freshwater interface, and can be used to address issues in conservation and natural resource management (i.e. diet and habitat use of endangered or commercially important species). In addition, the use of biominerals allows ecological and environmental processes to be tracked over time, extending current applications (Table 3). For example, sulfur dioxide pollution, which can have serious impacts to ecosystems, human health and climate, could be potentially 
Table 3. Potential ecological and environmental application of sulfur isotope signatures. Italics = tissue and/or mineral type

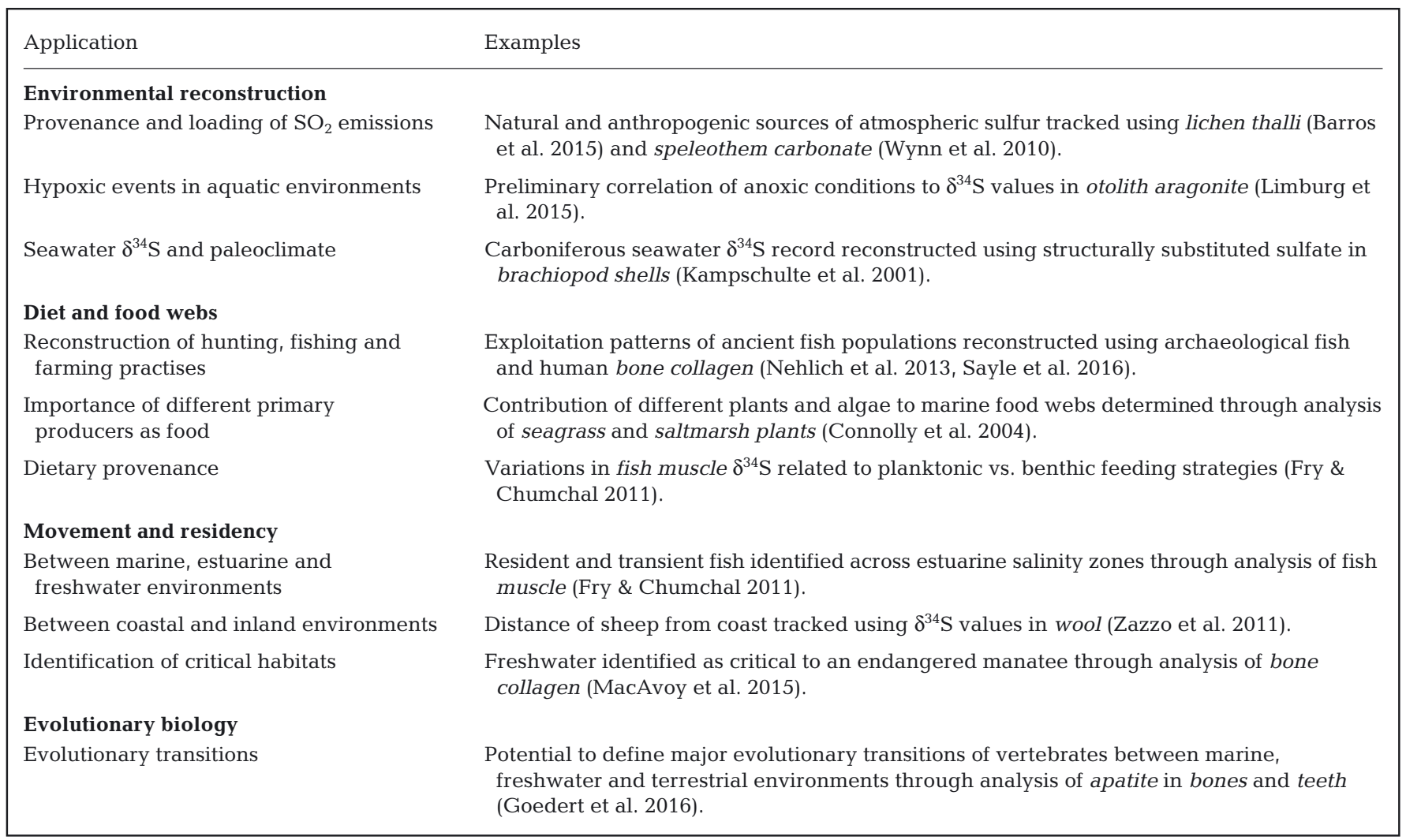

tracked in biominerals (i.e. atmospheric sulfur is assimilated by plants and algae, through which it is then passed onto aquatic and terrestrial consumers). Understanding changes in the loading and provenance of sulfur dioxide in the atmosphere could provide critical information regarding the efficacy of legislation and mitigation measures (Wynn et al. 2010, Barros et al. 2015). Furthermore, structurally substituted sulfate in biogenic carbonates can provide an accurate record of the sulfur isotope composition of ancient oceans, helping to uncover global environmental change over geological time scales (Kampschulte \& Strauss 2004, Perrin et al. 2017). Determining the presence of structurally substituted sulfate in other structures (e.g. otoliths) would further extend the potential of sulfur isotope analysis in biominerals.

The limited number of studies conducted to date, however, is telling of the challenges that may be faced when analysing sulfur isotopes in biominerals. Standard techniques (i.e. micromilling and subsequent analysis using mass spectrometry) used for the targeted analysis of light isotopes in otoliths, for instance, cannot be used due to the low concentrations of sulfur in the otolith. Although SIMS is well suited to the analysis of biominerals (high spatial resolution and low detection limits), availability of instrumentation is limited (in our experience), as well as the number of samples that can be analysed within a given time frame (small sample sizes being a limitation of this study and other studies analysing sulfur isotopes in otoliths). Further, sulfur isotope standards for otoliths and other biominerals need to be developed, commercially or in-house, so data cannot only be calibrated against the internationally accepted standard (VCDT), but also be comparable among laboratory and field studies. This calibration would also allow otolith values to be directly related to diet and water values and allow proportional contributions of diet and water to be calculated (e.g. Doubleday et al. 2013). Standards with a known isotopic value can be developed from relevant biominerals, if material with homogenous sulfur isotope distributions can be found (e.g. coral standard used for speleothem carbonate; Wynn et al. 2010), or be synthetically produced (e.g. Weber et al. 2002). Despite these challenges, sulfur isotope research crosses many disciplines, from geology to archaeology and food science; tapping into these multi-disciplinary studies will help progress analytical methods and protocols. 
Biominerals allow us to reconstruct long-term ecological and environmental datasets retrospectively, which can be logistically difficult and expensive to obtain using traditional observational approaches. Such datasets are rare, particularly for aquatic environments (Richardson \& Poloczanska 2008), but are vital for determining how populations and communities respond to environmental change, as well as for predicting what our future ecosystems may look like. Therefore, improving analytical methods and extending current applications of sulfur isotope analysis in biominerals is a worthwhile pursuit.

Acknowledgements. We thank Kayla Gilmore and Matthew McMillan for their assistance with fish husbandry and otolith dissections. This research was funded by an ARC Discovery grant (DP110100716) and Future Fellowship (FT100100767) awarded to B.M.G. The Nu instruments CF-IRMS and associated elemental analyzer were funded through an ARC LIEF grant (LE120100054). All animal handling and experimental procedures were approved by the Animal Ethics Committee at the University of Adelaide (permit no. S-2011-010). We acknowledge the facilities, and the scientific and technical assistance of the Australian Microscopy \& Microanalysis Research Facility at the Centre for Microscopy, Characterisation \& Analysis, The University of Western Australia, a facility funded by the University, State and Commonwealth Governments.

\section{LITERATURE CITED}

Barros C, Pinho P, Durão R, Augusto S, Máguas C, Pereira MJ, Branquinho C (2015) Disentangling natural and anthropogenic sources of atmospheric sulfur in an industrial region using biomonitors. Environ Sci Technol 49:2222-2229

Boecklen WJ, Yarnes CT, Cook BA, James AC (2011) On the use of stable isotopes in trophic ecology. Annu Rev Ecol Evol Syst 42:411-440

Campana SE (1999) Chemistry and composition of fish otoliths: pathways, mechanisms and applications. Mar Ecol Prog Ser 188:263-297

* Connolly RM, Guest MA, Melville AJ, Oakes JM (2004) Sulfur stable isotopes separate producers in marine foodweb analysis. Oecologia 138:161-167

Dauphin Y, Dufour E (2008) Nanostructures of the aragonitic otolith of cod (Gadus morhua). Micron 39:891-896

* Doubleday ZA, Izzo C, Woodcock SH, Gillanders BM (2013) Relative contribution of water and diet to otolith chemistry in freshwater fish. Aquat Biol 18:271-280

Fry B, Chumchal MM (2011) Sulfur stable isotope indicators of residency in estuarine fish. Limnol Oceanogr 56: 1563-1576

Godbout L, Trudel M, Irvine JR, Wood CC, Grove MJ, Schmitt AK, McKeegan KD (2010) Sulfur isotopes in otoliths allow discrimination of anadromous and nonanadromous ecotypes of sockeye salmon (Oncorhynchus nerka). Environ Biol Fishes 89:521-532

Goedert J, Fourel F, Amiot R, Simon L, Lécuyer C (2016) High precision ${ }^{34} \mathrm{~S} /{ }^{32} \mathrm{~S}$ measurements in vertebrate bioapatites using purge and trap EA IRMS technology.
Rapid Commun Mass Spectrom 30:2002-2008

Izzo C, Doubleday ZA, Schultz AG, Woodcock SH, Gillanders BM (2015) Contribution of water chemistry and fish condition to otolith chemistry: comparisons across salinity environments. J Fish Biol 86:1680-1698

Izzo C, Doubleday ZA, Gillanders BM (2016) Where do elements bind within the otoliths of fish? Mar Freshw Res 67:1072-1076

* Izzo C, Manetti D, Doubleday ZA, Gillanders BM (2017) Calibrating the element composition of Donax deltoides shells as a palaeo-salinity proxy. Palaeogeogr Palaeoclimatol Palaeoecol 484:89-96

Johnson RC, Weber PK, Wikert JD, Workman ML, MacFarlane RB, Grove MJ, Schmitt AK (2012) Managed metapopulations: Do salmon hatchery 'sources' lead to in-river 'sinks' in conservation? PLOS ONE 7:e28880

Kalish JM (1989) Otolith microchemistry: validation of the effects of physiology, age and environment on otolith composition. J Exp Mar Biol Ecol 132:151-178

Kampschulte A, Strauss H (2004) The sulfur isotopic evolution of Phanerozoic seawater based on the analysis of structurally substituted sulfate in carbonates. Chem Geol 204:255-286

Kampschulte A, Bruckschen P, Strauss H (2001) The sulphur isotopic composition of trace sulphates in Carboniferous brachiopods: implications for coeval seawater, correlation with other geochemical cycles and isotope stratigraphy. Chem Geol 175:149-173

พ Li P, Mai K, Trushenski J, Wu G (2009) New developments in fish amino acid nutrition: towards functional and environmentally oriented aquafeeds. Amino Acids 37: $43-53$

KLimburg KE, Olson C, Walther Y, Dale D, Slomp CP, Høie H (2011) Tracking Baltic hypoxia and cod migration over millennia with natural tags. Proc Natl Acad Sci USA 108: E177-E182

พ Limburg KE, Walther BD, Lu Z, Jackman G and others (2015) In search of the dead zone: use of otoliths for tracking fish exposure to hypoxia. J Mar Syst 141:167-178

* MacAvoy SE, Bacalan V, Kazantseva M, Rhodes J, Kim K (2015) Sulfur isotopes show importance of freshwater primary production for Florida manatees. Mar Mamm Sci 31:720-725

Martin JE, Tacail T, Balter V, Smith A (2017) Non traditional isotope perspectives in vertebrate palaeobiology. Palaeontology 60:485-502

*McCutchan JH, Lewis WM, Kendall C, McGrath CC (2003) Variation in trophic shift for stable isotope ratios of carbon, nitrogen, and sulfur. Oikos 102:378-390

*McFadden A, Wade B, Izzo C, Gillanders B, Lenehan C, Pring A (2016) Quantitative electron microprobe mapping of otoliths suggests elemental incorporation is affected by organic matrices: implications for the interpretation of otolith chemistry. Mar Freshw Res 67:889-898

Mugiya Y, Iketsu H (1987) Uptake of asparatic acid and sulfate by calcified tissues in goldfish and tilapia. Bull Fac Fish Hokkaido Univ 38:185-190

*Murayama E, Takagi Y, Ohira T, Davis JG, Greene MI, Nagasawa H (2002) Fish otolith contains a unique structural protein, otolin-1. Eur J Biochem 269:688-696

Nehlich O (2015) The application of sulphur isotope analyses in archaeological research: a review. Earth Sci Rev 142:1-17

Nehlich O, Barrett JH, Richards MP (2013) Spatial variability in sulphur isotope values of archaeological and mod- 
ern cod (Gadus morhua). Rapid Commun Mass Spectrom 27:2255-2262

Nelson J, Hanson CW, Koenig C, Chanton J (2011) Influence of diet on stable carbon isotope composition in otoliths of juvenile red drum Sciaenops ocellatus. Aquat Biol 13: 89-95

Perrin J, Rivard C, Vielzeuf D, Laporte D and others (2017) The coordination of sulfur in synthetic and biogenic Mg calcites: the red coral case. Geochim Cosmochim Acta 197:226-244

Peterson BJ, Fry B (1987) Stable isotopes in ecosystem studies. Annu Rev Ecol Syst 18:293-320

Richardson AJ, Poloczanska ES (2008) Under-resourced, under threat. Science 320:1294-1295

Rowell K, Dettman DL, Dietz R (2010) Nitrogen isotopes in otoliths reconstruct ancient trophic position. Environ Biol Fishes 89:415-425

Rubenstein DR, Hobson KA (2004) From birds to butterflies: animal movement patterns and stable isotopes. Trends Ecol Evol 19:256-263

Sayle KL, Hamilton WD, Cook GT, Ascough PL, Gestsdóttir

Editorial responsibility: Yves Cherel, Villiers-en-Bois, France
H, McGovern TH (2016) Deciphering diet and monitoring movement: multiple stable isotope analysis of the viking age settlement at Hofstaðir, Lake Mývatn, Iceland. Am J Phys Anthropol 160:126-136

Thode HG (1991) Sulfur isotopes in nature and the environment: an overview. In: Krouse HR, Grinenko VA (eds) Stable isotopes: natural and anthropogenic sulfur in the environment. John Wiley \& Sons, Chichester, p 1-26

* Trust BA, Fry B (1992) Stable sulphur isotopes in plants: a review. Plant Cell Environ 15:1105-1110

Weber PK, Hutcheon ID, McKeegan KD, Ingram BL (2002) Otolith sulfur isotope method to reconstruct salmon (Oncorhynchus tshawytscha) life history. Can J Fish Aquat Sci 59:587-591

*Wynn PM, Fairchild IJ, Frisia S, Spötl C, Baker A, Borsato A (2010) High-resolution sulphur isotope analysis of speleothem carbonate by secondary ionisation mass spectrometry. Chem Geol 271:101-107

Kazzo A, Monahan F, Moloney A, Green S, Schmidt O (2011) Sulphur isotopes in animal hair track distance to sea. Rapid Commun Mass Spectrom 25:2371-2378

Submitted: February 28, 2017; Accepted: April 23, 2018

Proofs received from author(s): June 7, 2018 